\title{
Non-Alcoholic Fatty Liver Disease in Cuba
}

\author{
Marlen I. Castellanos-Fernández MD PhD, Eduardo Crespo-Ramírez MD MS, Sergio del Valle-Díaz MD MS, \\ Eduardo Barreto-Suárez MD MS, Javier O. Díaz-Elías MD MS, Lorenzo Santaló-Rodríguez MD, Sahili Corrales-Alonso MD, \\ Ignacio Morales-Martínez MD, Elisa Cedeño-Ramírez MD, Teresita Pérez-González MD, Sila M. González-Suero MD MS, \\ Caridad Ruenes-Domech MD MS, Mirtha Infante-Velázquez MD PhD, Susana Á. Borges-González MD MS, \\ Angela Elvírez-Gutiérrez MD MS, Sacha Lazo-del Vallín MD MS, Oscar M. Villa-Jiménez MD MS, \\ Liana M. Labrada-Moreno MD MS
}

\begin{abstract}
INTRODUCTION With a global adult prevalence of $24 \%$, nonalcoholic fatty liver disease is a global health problem that parallels the worldwide increase of obesity. Its frequency, clinical characteristics and related diseases in Cuba remain unknown.

OBJECTIVE Describe the clinical characteristics, comorbidities and personal habits of patients with non-alcoholic fatty liver disease who are being treated in secondary and tertiary health facilities in seven Cuban provinces.

METHODS A cross-sectional, multicenter study was carried out in 6601 adults seen at gastroenterology outpatient clinics of nine hospitals in seven Cuban provinces from September 2018 through May 2019. Non-alcoholic fatty liver disease was diagnosed by abdominal ultrasound. The study included 1070 patients who met the diagnostic and study criteria and agreed to participate. Their personal habits and anthropometric and clinical characteristics, comorbidities and other aspects of their medical histories were recorded.
\end{abstract}

\section{INTRODUCTION}

Non-alcoholic fatty liver disease (NAFLD) includes a broad spectrum of metabolic damage associated with fatty deposits in the liver. Its diagnosis excludes other causes that may lead to steatosis, such as excessive alcohol consumption, viral infections, use of steatogenic drugs and/or hereditary disorders.[1]

NAFLD is generally diagnosed in one of three clinical scenarios: patients with abnormal liver enzymes, abnormalities in abdominal imaging or clinical characteristics associated with metabolic syndrome (MetS).[1-3] NAFLD has a diverse clinical presentation, and diagnosis is established when $>5 \%$ of liver cells are composed of fat. Although a liver biopsy remains the gold standard, noninvasive diagnosis of NAFLD can be carried out via liver imaging in most patients.[4] This clinical form is known as non-alcoholic fatty liver (NAFL), which, by definition, does not progress beyond the first stages of liver disease. Another form is non-alcoholic steatohepatitis accompanied by necroinflammation of hepatocytes with or without liver fibrosis, considered a type of progressive liver disease that leads to fibrosis in $41 \%$ of cases. Hepatocellular carcinoma is detected in $2 \%-3 \%$ of patients, with annual mortality rates estimated at 25.6 per 1000 population.[5,6]

\section{IMPORTANCE}

This is the first study of the frequency of non-alcoholic liver disease in Cuba, for which there were no national data available at the time this article was written.
RESULTS Of the 1070 participants, $60.7 \%$ (649) were women. Participants' average age was 54.5 years and average body mass index was $30.5 \mathrm{~kg} / \mathrm{m} 2$. A total of $397(37.1 \%)$ were overweight and $574(53.6 \%)$ were obese, $945(88.3 \%)$ led a sedentary lifestyle, $564(52.7 \%)$ had high blood pressure, $406(37.9 \%)$ had lipid disorders and $301(28.1 \%)$ were diabetic. While 484 (45.2\%) of patients were asymptomatic, the most frequent clinical signs and symptoms were fatigue (262; $24.5 \%)$, dyspepsia $(209 ; 19.5 \%)$, abdominal pain $(306 ; 28.5 \%)$ and hepatomegaly (189; $17.7 \%)$. Liver cirrhosis was present in $37(3.5 \%)$ patients at the time of diagnosis. Family history of type 2 diabetes mellitus and obesity were identified in $391(36.5 \%)$ and $279(26.1 \%)$ of participants, respectively.

CONCLUSIONS Prevalence of non-alcoholic fatty liver disease in these Cuban patients coincides with that reported in the Caribbean region, which has high levels of obesity, overweight and sedentary lifestyles. Most were asymptomatic, female or had metabolism-related comorbidities such as high blood pressure, type 2 diabetes mellitus and dyslipidemia.

KEYWORDS Non-alcoholic fatty liver disease, overweight, obesity, type 2 diabetes mellitus, Cuba

The epidemic of chronic liver disease is related to the burden of NAFLD, itself associated with the global increase in obesity. $[7,8]$ An overall prevalence of $24 \%$ is reported globally with highest rates in the Middle East (32\%) and South America (31\%), followed by Asia $(27 \%)$ and Europe $(23 \%)$; it is less common in Africa (14\%).[8]

Since obesity is associated with presence and severity of NAFLD, it is useful to note that in $2016,39 \%$ of adults worldwide $(39 \%$ of men and $40 \%$ of women) were overweight, and some $13 \%(11 \%$ of men and $15 \%$ of women) were obese.[9] Prevalence of excess weight and obesity in Latin America is much higher $62.8 \%$ in men and $59.8 \%$ in women), explaining why estimated NAFLD rates are increasing in this region. Based on obesity rates, it is estimated that NAFLD prevalence is $26 \%$ in Mexico and $15 \%-20 \%$ in Central America.[10-12]

There is a bidirectional association between NAFLD and the components of MetS, as the latter is frequent in NAFLD patients and MetS, in turn, increases risk for NAFLD. NAFLD has been reported in $22.5 \%$ of patients with type 2 diabetes mellitus (DM), in $51.3 \%$ of those who are obese, $42.5 \%$ of patients with MetS, $39.3 \%$ of hypertensive patients and $69.2 \%$ of those with hyperlipidemia.[4]

NAFLD prevalence is expected to increase, accompanying the upward trend of the global obesity epidemic and the increase observed in type 2 DM.[6] A number of MetS characteristics, particularly type $2 \mathrm{DM}$ and family history of MetS, are risk factors for NAFLD.[13] 
In Cuba, overweight and obesity are major health problems and their prevalence increased from $35.5 \%$ in 1982 to $44.3 \%$ in 2012. [14] In 2010, the rates for high blood pressure (HBP) and type 2 DM were 202.7 and 40.4 per 1000 population, respectively. In 2019, these rates increased to 233 and 66.7.[15,16]

Post-mortem studies of 3317 persons who had been diagnosed with NALFD from 1991 to 2009 revealed that 53\% had simple hepatic steatosis, $44.2 \%$ steatohepatitis and $2.6 \%$ hepatic steatosis with fibrosis or cirrhosis, which highlights the impact this disease has on the liver. In this group, the main cause of death was coronary atherosclerosis.[17]

In Cuba, NAFLD is most often diagnosed in gastroenterology services and its current prevalence in the country is unknown. The purpose of our study was to describe the clinical characteristics at diagnosis, associated comorbidities and personal habits of NAFLD patients seen in secondary and tertiary health facilities in seven Cuban provinces.

\section{METHODS}

Design and sample A cross-sectional study was carried out from September 2018 through May 2019 in patients seen at gastroenterology outpatient services in nine Cuban hospitals in seven provinces. These services provided care and monitoring of patients with gastrointestinal, liver, biliary and pancreatic conditions who were referred from community-based polyclinics, family doctors or other specialists. NAFLD diagnosis was based on presence of hepatic steatosis in abdominal ultrasound (US) in the absence of known secondary causes of fat accumulation in the liver, in accordance with the criteria of the American Association for the Study of Liver Diseases.[1]

Personal and family medical history, personal habits, medications used at the time of recruitment and anthropometric data were obtained through a questionnaire developed for that purpose.

A total of 6601 patients seen in gastroenterology consultations during the study period were considered. Those who met NAFLD diagnostic and our own research criteria were included. Excluded were persons who did not want to participate and those who had other causes of chronic liver disease that can lead to steatosis (Figure 1). Specific traits that led to exclusion were: 1) Alcoholics or individuals who consume more than the maximum recommended weekly alcohol intake,[1] 2) individuals who suffered from chronic autoimmune or inherited liver diseases, 3) individuals who had a history of steatogenic drug use in the six months prior to recruitment date (corticosteroids, methotrexate, tetracycline, amiodarone, diltiazem or tamoxifen), 4) women who were pregnant, breastfeeding or taking hormonal contraceptives, 5) those diagnosed with an active malignant tumor and 6) individuals who tested positive for the surface antigen of the hepatitis $B$ virus (HBV) or hepatitis $C$ virus (HCV) antibodies. We included patients with a history of HCV infection when the viral load had remained negative for more than a year.

Patients were recruited consecutively during the study period, resulting in inclusion of 1070 persons: 420 men (39.3\%) and 650 women $(60.7 \%)$, with a median age of 55 years and age range 18 to 88 years.
Figure 1: Flow of patients in the study. Cuba, 2018-2019

Evaluated in clinic

September 2018 to May 2019

$$
n=6601
$$

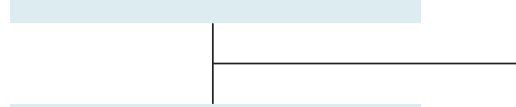

Excluded due to other causes of liver disease

Eligible with probable diagnosis of NAFLD $n=1291$ $n=5310(80.4 \%)$

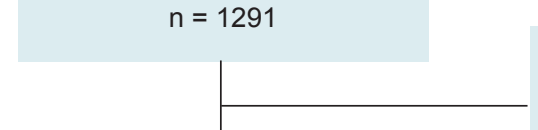

Refused to participate in the study $\mathrm{n}=96(7.4 \%)$

Responded with the required data $n=1070$

Didn't complete the evaluation $n=125(9.7 \%)$

NAFLD diagnosis by abdominal US was defined by presence of liver homogeneous or heterogeneous hyperechogenicity (increased echogenicity with respect to the kidney parenchyma) and attenuation of the liver's deep structures (diaphragm, vessels, posterior segments). For US diagnosis of steatosis, longitudinal and transverse cuts were made with a low frequency $(2.5-5$ $\mathrm{MHz}$ ) convex probe. The following ultrasound scanners were used: Toshiba Aplio 300 (Toshiba Medical Systems Europe, The Netherlands), Aloka SSD-4000 (Hitachi Aloka Medical, Japan) and EPIQ 5 (Philips Ltd, UK). US was performed and diagnosis made by radiologists in all units participating in the study.

Sex, age, area of residence (urban or rural) and skin color (white, black, or mestizo) were recorded according to the classification of Cuba's National Statistics and Information Bureau (http://www .onei.gob.cu/).

Actual weight $(\mathrm{AW}, \mathrm{kg})$ and height $(\mathrm{cm})$ were measured at the time of study enrollment and body mass index (BMI) calculated. A BMI of $<18 \mathrm{~kg} / \mathrm{m}^{2}$ was considered underweight, $18-24.9 \mathrm{~kg} / \mathrm{m}^{2}$ normal weight, $25-29.9 \mathrm{~kg} / \mathrm{m}^{2}$ overweight and $\geq 30 \mathrm{~kg} / \mathrm{m}^{2}$ obese. Waist circumference was measured to ascertain central obesity, a condition associated with metabolic complications. Criteria of the National Cholesterol Education Program Adult Treatment Panel III (NCEP ATPIII) were used as reference points for waist circumference: $102 \mathrm{~cm}$ in men and $88 \mathrm{~cm}$ in women.[18] Anthropometric measurements were carried out during patient recruitment and doctor visits, according to methodology outlined for nutritional studies by the Nutrition and Food Hygiene Institute of Cuba.[19] A calculation was to determine ideal weight (IW), with IW $=0.75$ (height in $\mathrm{cm}-150$ ) +50 and was used to determine the difference between actual and ideal weight according to the expression IW $=(\text { AW-IW })^{*} 100 / I W$.

Any medical history of interest was recorded: HBP, type $2 \mathrm{DM}$, hyperuricemia, dyslipidemia (high cholesterol and/or triglycerides), 
thyroid disease, myocardial infarction and cancer, as well as treatments for these conditions. Medical history considered in first-degree relatives were fatty liver, cirrhosis of the liver, type 2 DM, obesity and cancer.

Personal habits considered included smoking, degree of physical activity and alcohol consumption. These were categorized as follows:

Smoking Smoker: regular or occasional consumption of tobacco products; non-smoker: no consumption of tobacco products.

Physical activity Adapted from WHO criteria on physical activity. [20] Sedentary lifestyle: physical activity $<15$ minutes $<3$ times per week during the last quarter, or performing only everyday tasks (occupational activities, traveling, household chores and recreational activities). Moderate or intense physical activity: walking (30 minutes a day $\geq 5$ days a week), games, dancing, non-intense extra work, light weights $(\leq 20 \mathrm{~kg})$ or jogging, racing, aerobics, sports, intense work, heavy weights ( $\geq 20 \mathrm{~kg}$ ).

Alcohol consumption We used guidelines of the American Association for the Study of Liver Diseases and the National Institute on Alcohol Abuse and Alcoholism (USA) to define risks associated with alcohol consumption, as women who consume $\geq 7$ standard drink units and men who consume $\geq 14$ every week are at increased risk for alcohol-related problems.

Patients who had no symptoms and in which NAFLD was found incidentally by US ordered for other reasons, or because they had abnormal liver enzymes, were recorded as asymptomatic. Patients were recorded as symptomatic if they reported any symptoms usually linked to NAFLD such as: fatigue, chronic abdominal pain, myalgia and dyspepsia. Among the included signs detected during physical examination were hepatomegaly, xanthomas/xanthelasmas and signs of liver cirrhosis (noninvasive US diagnosis or presence of edema, ascites, splenomegaly, collateral circulation, jaundice, palmar erythema, telangiectasia, petechiae, ecchymosis).

In the initial patient recruitment consultation, blood pressure (BP) was measured and the average of the last two measurements from a total of three measurements, carried out in intervals of one minute with a mercury sphygmomanometer (Kindcare Medical System, China) were recorded. In accordance with the characteristics of the sample, $\geq 130 / 85 \mathrm{mmHg}$ was considered high, following the criteria of the American College of Cardiology, the American Heart Association (USA), and the working group for treatment of high blood pressure of the European Society of Cardiology and the European Society of Hypertension.[22,23]

Infection by hepatitis B and $C$ viruses was ruled out by using an enzyme-linked immunosorbent assay (ELISA) kit (Ultra Micro Analytical System, SUMA, Tecnosuma International, Cuba) for the surface antigen of the hepatitis $B$ virus ( $\mathrm{HBsAg})$, the hepatitis $B$ core antibody (anti-HBc) and hepatitis $\mathrm{C}$ virus antibody (AcHCV).

To ensure consistency of information reported at participating sites, criteria unification workshops were held for researchers and guidelines were established for information collection and data entry in an Excel (Microsoft, USA) database designed for this purpose. The principal investigator at each center controlled the quality of data and standardization of procedures according to the established protocol.

Ethics The study was approved by the research ethics committees of Cuba's Gastroenterology Institute and of participating hospitals. Patients were provided with detailed information on study purposes, importance of their participation and benefits. There were no potential risks to patient health. All participants provided written informed consent. The information was kept confidential and in no case will participant identity be revealed.

Diagnostic tools were selected according to principles of maximum beneficence. They followed the Declaration of Helsinki's Good Clinical Practices guidelines[24] and the Guidelines of the Council for International Organizations of Medical Sciences.[25]

Patients who did not meet the selection criteria were informed of the reasons for their non-inclusion in the study and were sent to specialized clinics in each institution for monitoring and control. Benefits received by the patients included the diagnosis and treatment of diseases.

Statistical analysis Variables were processed in a database created in the statistical package for social sciences for Windows version 21.0 (IBM-SPSS, USA). Descriptive statistics, absolute and relative frequencies, averages and standard deviations and the difference of the average of waist circumference $(\mathrm{cm})$ with respect to the cutoff point in both sexes were calculated (confidence interval, 95\%).

\section{RESULTS}

Of the 1070 patients studied, $786(73.5 \%)$ resided in provinces in Cuba's western region, $169(15.8 \%)$ in the central region and 115 $(10.7 \%)$ in eastern Cuba; 650 participants $(60.7 \%)$ were women. NAFLD was diagnosed in $16.2 \%$ of all participants. The range of the frequency of patients with NAFLD among centers was $10.8 \%-$ $19.5 \%$ (Table 1).

Sociodemographic characteristics, personal habits and personal medical history of the patients revealed that sedentary lifestyle was a frequently observed phenomenon. HBP, dyslipidemia and type $2 \mathrm{DM}$ were the most frequent previous medical issues, followed by acute myocardial infarction, hyperuricemia, thyroid disease and cancer (Table 2).

Average BMI of participants was $30.5 \mathrm{~kg} / \mathrm{m}^{2}$, or grade I obesity. Distribution of BMI values is shown in Table 3 , where the high percentages of overweight and obesity $(37.1 \%$ and $53.6 \%$, respectively) are of particular note. Average waist circumference was $101.2 \mathrm{~cm}$ in men and $99 \mathrm{~cm}$ in women. Difference in average waist circumference $(\mathrm{cm})$ with respect to the cut-off point in both sexes was $-0.77(-1.9$ to $-0.4 ; p=0.208)$ in men and 11.05 (10.0 to $12.0 ; p<0.001$ ) in women, which implies that women had a rate of central obesity averaging $11 \mathrm{~cm}$ above the reference value for abdominal circumference, while men had a rate $0.7 \mathrm{~cm}$ below the reference value. Average excess weight of patients with respect to ideal weight was $36.3 \mathrm{~kg}$.

The most frequent symptoms and signs, blood pressure readings, and the proportion of patients with liver cirrhosis can be found 
Table 1: Total patients and study participants by center and province

\begin{tabular}{|c|c|c|c|c|}
\hline Province & Hospital & $\begin{array}{c}\text { Study } \\
\text { participants } \\
\text { (n) }\end{array}$ & $\begin{array}{l}\text { Total } \\
\text { patients } \\
\text { seen }(n)\end{array}$ & $\begin{array}{l}\text { Proportion } \\
\text { of NAFLD } \\
(\%)\end{array}$ \\
\hline Pinar del Río & $\begin{array}{l}\text { Abel Santamaría Cuadrado } \\
\text { Provincial Clinical-Surgical } \\
\text { Hospital }\end{array}$ & 301 & 1536 & 19.6 \\
\hline Santiago de Cuba & $\begin{array}{l}\text { Saturnino Lora Torres } \\
\text { Provincial Clinical-Surgical } \\
\text { Teaching Hospital }\end{array}$ & 115 & 970 & 11.9 \\
\hline Camagüey & $\begin{array}{l}\text { Manuel Ascunce Domenech } \\
\text { Provincial Clinical-Surgical } \\
\text { Teaching Hospital }\end{array}$ & 109 & 656 & 16.6 \\
\hline Matanzas & $\begin{array}{l}\text { Faustino Pérez Hernández } \\
\text { University Clinical-Surgical } \\
\text { Teaching Hospital }\end{array}$ & 60 & 432 & 13.9 \\
\hline Artemisa & $\begin{array}{l}\text { Iván Portuondo General } \\
\text { Teaching Hospital }\end{array}$ & 28 & 257 & 10.9 \\
\hline Villa Clara & $\begin{array}{l}\text { Celestino Hernández Robau } \\
\text { Provincial Oncology University } \\
\text { Hospital }\end{array}$ & 60 & 442 & 13.6 \\
\hline Havana & $\begin{array}{l}\text { Calixto García University } \\
\text { Clinical-Surgical Hospital }\end{array}$ & 99 & 652 & 15.2 \\
\hline Havana & $\begin{array}{l}\text { Manuel Fajardo Clinical- } \\
\text { Surgical Teaching Hospital }\end{array}$ & 45 & 310 & 14.5 \\
\hline Havana & Gastroenterology Institute & 253 & 1346 & 18.8 \\
\hline Total & & 1070 & 6601 & 16.2 \\
\hline
\end{tabular}

NAFLD: Non-alcoholic fatty liver disease

Table 2: Sociodemographic characteristics, personal habits and medical history of study participants

\begin{tabular}{|l|r|}
\hline Variable & \multicolumn{1}{c|}{$\begin{array}{c}\text { Total } \\
\mathbf{n}=1070\end{array}$} \\
\hline Age (years) (mean/SD) & $54.5(11.1)$ \\
\hline Skin color, $\mathbf{n}(\%)$ & $698(65.2)$ \\
White & $156(14.6)$ \\
Black & $216(20.2)$ \\
Mestizo & \\
\hline Area of residence, $\mathbf{n}(\%)$ & $1010(94.4)$ \\
Urban & $60(5.6)$ \\
Rural & $183(17.1)$ \\
\hline Smokers, $\mathbf{n}$ (\%) & \\
\hline Physical activity, $\mathbf{n}(\%)$ & $945(88.3)$ \\
\hline Sedentary & $125(11.7)$ \\
\hline Moderate or Intense & \\
\hline Personal medical history, $\mathbf{n}(\%)$ & $564(52.7)$ \\
\hline High blood pressure & $406(37.9)$ \\
\hline Dyslipidemia & $301(28.1)$ \\
\hline Diabetes mellitus & $191(17.9)$ \\
\hline Myocardial Infarction & $142(13.3)$ \\
\hline Hyperuricemia & $59(5.5)$ \\
\hline Thyroid Diseases & $26(2.4)$ \\
\hline Cancer & \\
\hline
\end{tabular}

in Table 3, in which fatigue, dyspepsia, abdominal pain, and hepatomegaly stand out due to their higher frequencies. Nearly half of the patients were asymptomatic.

The most frequent conditions observed in the patients' family medical history were type $2 \mathrm{DM}$, obesity and cancer, with notably high values for the first two (Table 4).

\section{DISCUSSION}

This is the first study on the disease conducted with a large number of patients and in several hospitals in three regions of Cuba. It fills a gap in knowledge on NAFLD frequency in Cuba, although smaller-sample studies have been published.[26-30]

Despite the fact that this study was carried out in each patient's gastroenterology department, which allows for standardized measuring conditions, its results do not differ from those reported in the literature. Fleischman[31] carried out a multi-ethnic study on atherosclerosis (MESA) in a Hispanic population in the United States, finding a NAFLD prevalence of $33 \%$ in those of Mexican descent, $16 \%$ in those of Dominican descent and $18 \%$ in those of Puerto Rican descent, indicating this disease is common among Hispanics in the USA. Various Latin American countries have reported relatively high rates: Brazil (18.0\%-35.2\%), Chile (23\%) and Colombia (26.6\%).[11,32-36] The proportion of patients in this study with NAFLD as measured by center and by province did not exceed $20 \%$.

Prevalence varies according to study method, population characteristics, presence of risk factor, and area of residence, among other factors. NAFLD frequency detected in this study by US was similar to estimates based on obesity prevalence, which are between $15 \%$ and $20 \%$ for Central America and the Caribbean.[11]

The most recent survey on risk factors and non-communicable diseases in Cubans[37] revealed smoking frequency at $23.7 \%$; excess weight and obesity at $29.8 \%$ and $13.7 \%$, respectively; sedentary lifestyle with no physical activity at $40.4 \%$; and prevalence of chronic diseases-such as HBP, type 2 DM and dyslipidemia-at $30.9 \%, 10 \%$ and $4.6 \%$, respectively. Average $\mathrm{BMI}$ and waist circumference was $24.5 \mathrm{~kg} / \mathrm{m}^{2}$ and $85.1 \mathrm{~cm}$ in Cuban men and $25.5 \mathrm{~kg} / \mathrm{m}^{2}$ and $81.8 \mathrm{~cm}$ in women.

In our study, the proportion of smokers was lower, and the relative frequencies of excess weight and obesity were between two and three times higher than those found in the national survey. The higher levels of central obesity and greater presence of metabolic comorbidities are distinctive characteristics that were expected in the sample with NAFLD, which is related to metabolic syndrome.[13] It should be noted that excess weight and obesity in the Cuban population is rising and is already a health problem in the country.[38]

The effects of tobacco on NAFLD progression is a source of controversy. A systematic review showed that both active and passive smoking are associated with this disease, but the mechanisms of this association are unknown because physical activity, diet type, caffeine consumption and some socio-economic factors act as potential confounding variables.[39] The average prevalence of smoking in the Cuban population is higher than that detected in this study.[37] 
Table 3: Anthropometric measurements, clinical signs and symptoms of study participants

\begin{tabular}{|c|c|}
\hline Variable & $\begin{array}{c}\text { Total } \\
n=1070\end{array}$ \\
\hline Mean (SD) & $30.5(4.6)$ \\
\hline Classification according to body mass index $\left(\mathrm{kg} / \mathrm{m}^{2}\right) \mathrm{n}(\%)$ & \\
\hline Underweight: <18 & $2(2)$ \\
\hline Normal weight: 18-24.9 & $97(9.1)$ \\
\hline Overweight: $25-29.9$ & $397(37.1)$ \\
\hline Obesity: $\geq 30$ & $574(53.6)$ \\
\hline $\begin{array}{l}\text { Variation of ideal weight }(\mathrm{kg}) \\
\text { Mean (SD) }\end{array}$ & $36.3(20.9)$ \\
\hline $\begin{array}{l}\mathrm{SBP}(\mathrm{mmHg}) \\
\text { Mean }(\mathrm{SD})\end{array}$ & $129(15)$ \\
\hline $\begin{array}{l}\mathrm{DBP}(\mathrm{mmHg}) \\
\text { Mean }(\mathrm{SD})\end{array}$ & $83(10)$ \\
\hline $\begin{array}{l}\text { HR (beats per min) } \\
\text { Mean (SD) }\end{array}$ & $79.1(8.3)$ \\
\hline $\begin{array}{l}\text { Asymptomatic } \\
\mathrm{n}(\%)\end{array}$ & $484(45.2)$ \\
\hline $\begin{array}{l}\text { Abdominal pain } \\
\mathrm{n}(\%)\end{array}$ & $306(28.6)$ \\
\hline $\begin{array}{l}\text { Fatigue } \\
\mathrm{n}(\%)\end{array}$ & $262(24.5)$ \\
\hline $\begin{array}{l}\text { Dyspepsia } \\
\text { n (\%) }\end{array}$ & $209(19.5)$ \\
\hline $\begin{array}{l}\text { Hepatomegaly } \\
\mathrm{n}(\%)\end{array}$ & $189(17.7)$ \\
\hline $\begin{array}{l}\text { Myalgia } \\
\mathrm{n}(\%)\end{array}$ & $70(6.5)$ \\
\hline $\begin{array}{l}\text { Xanthomas/xanthelasmas } \\
\mathrm{n}(\%)\end{array}$ & $70(6.5)$ \\
\hline $\begin{array}{l}\text { Liver cirrhosis } \\
\mathrm{n}(\%)\end{array}$ & $37(3.5)$ \\
\hline
\end{tabular}

Table 4: Family medical history of study participants

\begin{tabular}{l|r|}
\hline Variables & \multicolumn{1}{|c|}{$\mathbf{n}(\%)$} \\
\hline Diabetes & $391(36.5)$ \\
Yes & $619(57.9)$ \\
No & $60(5.6)$ \\
Unknown & \\
\hline Obesity & $279(26.1)$ \\
Yes & $731(68.3)$ \\
No & $60(5.6)$ \\
Unknown & \\
\hline Cancer & $210(19.6)$ \\
Yes & $800(74.8)$ \\
No & $60(5.6)$ \\
Unknown & \\
\hline NAFLD & $105(9.8)$ \\
Yes & $905(84.6)$ \\
No & $60(5.6)$ \\
Unknown & \\
\hline Cirrhosis & $57(5.3)$ \\
Yes & $953(89.1)$ \\
No & $60(5.6)$ \\
Unknown &
\end{tabular}

NAFLD: non-alcoholic fatty liver disease

The sedentary lifestyle of our study participants was more than twice the rate reported in the national survey (38.3\%),[37] and in Latin America and the Caribbean, (39.1\%)[14,40] although the rate of sedentary lifestyles among Cubans is one of the highest in the world.[37]
Globally, differences have been reported between men and women in terms of prevalence, risk factors, fibrosis, disease severity and symptoms associated with NAFLD. Being male is considered a NAFLD risk factor and prevalence as great as twice that for women has been reported. $[1,2,41]$ However, there is little consistency in the evidence since other studies show an increased risk for women,[42-44] consistent with our study's finding that NAFLD was more frequent in women than in men.

When the analysis is adjusted for age, studies reveal NAFLD prevalence and incidence is greater in women after menopause because body fat is redistributed toward the abdomen due to loss of estrogen's protective effects, a factor that favors appearance of MetS.[43-45]

Although it is known that insulin resistance and obesity are associated with the metabolic alterations characteristic of NAFLD,[46] some studies have reported a relatively high prevalence of NAFLD in lean people, particularly in young women, who are very unlikely to have insulin resistance and hypercholesterolemia and who have a lipid profile that is different from that of overweight or obese individuals. NAFLD frequency in lean patients in our study $(9.2 \%)$ is less than the $18 \%$ reported by Younossi.[47] This is a potential topic for further research.

NAFLD is considered a polygenic disease and an inherited condition involving genetic variants related to disease progression.[48,49] Higher frequencies of NAFLD have been reported in the Hispanic population than in Afro-descendants or indigenous Americans. These differences seem to be associated with genetic variations such as the patatin-like phospholipase domain-containing protein 3 gene (PNPLA-3), which is more frequent in Hispanics. These variations increase the risk of disease progression in persons who do not have metabolic syndrome, regardless of their dietary patterns and metabolic traits.[50] So far, there have been no genetic studies of this type in Cuba and skin color has proven to be unreliable as a proxy for these genetic variations, given the broad admixture in the Cuban population.[51,52]

It has been shown that family history of type $2 \mathrm{DM}$ is closely linked to NAFLD, with a high risk of nonalcoholic steatohepatitis (OR: 1.51, 95\% $\mathrm{Cl}=1.01-2.25 ; \mathrm{p}=0.04$ ) and fibrosis (OR: $1.49,95 \% \mathrm{Cl}=1.01-2.20$; $p=0.04),[13]$ which may explain the high frequency of type $2 \mathrm{DM}$ in family medical histories of patients with NAFLD. This should be taken into account when conducting population-based studies.

Liver cirrhosis was diagnosed in a proportion of patients that is alarming if we bear in mind that cirrhosis was not the main subject of this investigation. A large proportion of patients with cryptogenic cirrhosis presented frequent metabolic risk factors that, in most cases, suggested undiagnosed non-alcoholic steatohepatitis that developed undetected over time, and also that the diagnosis of cirrhosis was established at advanced stages.[53]

A multicenter study involving several countries, including Cuba, showed that patients with cirrhosis due to NAFLD (indicative of severe fibrosis) suffer complications related to chronic liver failure, while those with less severe fibrosis present with other conditions such as cancer (not liver cancer) and vascular complications. [54] Studies are needed to identify predictors of liver fibrosis and progression to cirrhosis in Cuban NAFLD patients who have conditions characteristic of metabolic syndrome. 
It was not possible to assess the reliability of measurements in the NAFLD ultrasound diagnosis, as they were carried out at a single point in time, by a single observer (a radiologist) and in differing clinical scenarios, using dissimilar ultrasound equipment. However, in order to minimize bias, standardized diagnostic criteria for this disease were used,[1] and the examination was carried out by the most highly-skilled radiologist in each center. The fact that $17 \%$ of eligible patients with a probable diagnosis of NAFLD were excluded from the study (either because they refused to participate or failed to complete the required information), may represent an underestimation bias of disease frequency. Regions within the country could not be compared and results cannot be generalized to the whole Cuban population, since for practical reasons most participants were recruited in western Cuba. However, outcomes are important as a first approach to the study of this disease in the country.

\section{CONCLUSIONS}

The proportion of NAFLD in these Cuban patients coincides with that reported in the wider Caribbean, which has a high frequency of obesity, overweight and sedentary lifestyles. Most NAFLD patients were asymptomatic, female or had metabolic-related comorbidities such as HBP, type 2 DM and dyslipidemia. In addition, type 2 DM and obesity were frequent in these patients' family medical histories.

\section{ACKNOWLEDGMENTS}

The authors thank Armando Borrego-Rivero and Rosaura PichsBrito, both biostatisticians at the Medical Records Department of the Gastroenterology Institute, for their administrative assistance. - 1h

\section{REFERENCES}

1. Chalasani N, Younossi Z, Lavine JE, Charlton M, Cusi K, Rinella M, et al. The diagnosis and management of nonalcoholic fatty liver disease: Practice guidance from the American Association for the Study of Liver Diseases. Hepatology [Internet]. 2018 Jan [cited 2019 Feb 19];67(1):328-57. Available at: https://doi.org/10.1002/hep.29367

2. European Association for the Study of the Liver (EASL); European Association for the Study of Obesity Diabetes (EASO). EASL-EASDEASO Clinical Practice Guidelines for the management of non-alcoholic fatty liver disease. Obes Facts [Internet]. 2016 May [cited 2020 Feb 19];9(2):65-90. Available at: https://doi .org/10.1159/000443344

3. Patel V, Sanyal AJ, Sterling R. Clinical presentation and patient evaluation in nonalcoholic fatty liver disease. Clin Liver Dis. 2016 May;20(2):277-92.

4. Cotter TG, Rinella M. Nonalcoholic fatty liver disease 2020: The State of the Disease. Gastroenterology. 2020 May;158(7):1851-64

5. Younossi ZM, Koenig $A B$, Abdelatif $D$, Fazel Y, Henry L, Wymer M. Global epidemiology of nonalcoholic fatty liver disease-meta-analytic assessment of prevalence, incidence, and outcomes. Hepatology [Internet]. 2016 Jul [cited 2020 Aug 26];64(1):73-84. Available at: https:// doi.org/10.1002/hep.28431

6. Paul S, Davis AM. Diagnosis and management of nonalcoholic fatty liver disease. JAMA. 2018 Dec 18;320(23):2474-5.

7. Loomba R, Sanyal AJ. The global NAFLD epidemic. Nat Rev Gastroenterol Hepatol. 2013 Nov;10(11):686-90.

8. Younossi Z, Anstee QM, Marietti M, Hardy T, Henry L, Eslam M, et al. Global burden of NAFLD and $\mathrm{NASH}$ : trends, predictions, risk factors and prevention. Nat Rev Gastroenterol Hepatol [Internet]. 2018 Jan;15(1):11-20. Available at: http:// dx.doi.org/10.1038/nrgastro.2017.109

9. World Health Organization [Internet]. Geneva: World Health Organization; c2020. Centro de prensa. Notas descriptivas. Obesidad y sobrepeso; 2020 [updated 2020 Apr 1; cited 2020 Jun10]. Available at: https://www.who.int/es/news-room/ fact-sheets/detail/obesity-and-overweight. Spanish.

10. World Health Organization [Internet]. Geneva: World Health Organization; c2020. Global Health Observatory (GHO). Reports. World health statistics 2016: monitoring health for the SDGs sustainable development goals. World Health Organization; 2016 [cited 2020 Feb 15]. Available at: https://www.who.int/gho/publications/ world health statistics/2016/en/

11. López-Velázquez JA, Silva-Vidal KV, PoncianoRodríguez G, Chávez-Tapia NC, Arrese M, Uribe
$M$, et al. The prevalence of nonalcoholic fatty liver disease in the Americas. Ann Hepatol. 2014 MarApr;13(2):166-78.

12. de Oliveira CPMS, Cotrim HP, Arrese M. Factores de riesgo de la enfermedad por hígado graso no alcohólico en poblaciones de Latinoamérica: situación actual y perspectivas. Clin Liver Dis (Hoboken). 2019 May 29;13(Suppl 1):S5-S8. Spanish.

13. Loomba R, Abraham M, Unalp A, Wilson L, Lavine J, Doo E, et al. Association between diabetes, family history of diabetes, and risk of nonalcoholic steatohepatitis and fibrosis. Hepatology. 2012 Sep;56(3):943-51.

14. Jiménez Acosta SM, Magaly $S$, Rodríguez Suárez A, Díaz Sánchez ME. La obesidad en Cuba. Una mirada a su evolución en diferentes grupos poblacionales. Rev Cubana Alimen Nutr. 2013;23(2):297-308. Spanish. Available at: http://www.revalnutricion sld.cu/index.php/rcan/article/view/299

15. National Health Statistics and Medical Records Division (CU). Anuario Estadístico de Salud 2019 [Internet]. Havana: Ministry of Public Health (CU); 2020 Apr [cited 2020 Jun 15]. 193 p. Available at: https://files.sld.cu/bvscuba/files/2020/05/Anua rio-Electr\%c3\%b3nico-Espa\%c3\%b1ol-2019 -ed-2020.pdf. Spanish.

16. National Health Statistics and Medical Records Division (CU). Anuario Estadístico de Salud 2010. Havana: Ministry of Public Health (CU); 2011 Apr [cited 2020 Jun 15]. 199 p. Available at: https://files.sld.cu/dne/files/2011/04/anuario -2010-e-sin-graficos1.pdf. Spanish.

17. Montero González T, Pérez Lorenzo M, Alarcón Arango I, Infante Velázquez M, Angulo Pérez O, Winogra Lay R, et al. Prevalencia de esteatosis hepática no alcohólica en autopsias y alteraciones morfológicas metabólicas relacionadas. Rev Cub Med Mil. 2011;40(1):32-9. Spanish.

18. Expert Panel on Detection, Evaluation and Treatment of High Blood Cholesterol in Adults. Executive Summary of The Third Report of The National Cholesterol Education Program (NCEP) Expert Panel on Detection, Evaluation, And Treatment of High Blood Cholesterol In Adults (Adult Treatment Panel III). JAMA [Internet]. 2001 May 16 [cited 2020 Feb 15];285(19):2486-97. Available at: https://jamanetwork.com/journals/jama/fullarti cle/vol $/ 285 / \mathrm{pg} / 2486$

19. Díaz Sánchez ME. Manual de técnicas antropométricas para estudios nutricionales. Havana: Nutrition and Food Hygiene Institute (CU); 2005. Spanish.

20. World Health Organization [Internet]. Geneva: World Health Organization; c2020. Estrategia mundial sobre régimen alimentario, actividad física y salud. ¿Qué se entiende por actividad moderada y actividad vigorosa?; 2019 [cited 2019 Dec 25]. Available at: https://www.who.int/ dietphysicalactivity/physical_activity_intensity/ es/. Spanish.

21. National Institute on Alcohol Abuse and Alcoholism (US). Helping Patients who Drink Too Much: A Clinician's Guide: Updated 2005 Edition [Internet]. Maryland: National Institutes of Health (US); 2005 [revised 2016 Jul; cited 2019 Dec 20]. 34 p. Available at: https://pubs.niaaa.nih.gov/publica tions/practitioner/cliniciansguide2005/guide.pdf

22. Reboussin DM, Allen NB, Griswold ME, Guallar E, Hong Y, Lackland DT, et al. Systematic Review for the 2017 ACC/AHA/AAPA/ABC/ACPM/AGS/APhA/ ASH/ASPC/NMA/PCNA Guideline for the Prevention, Detection, Evaluation, and Management of High Blood Pressure in Adults: A Report of the American College of Cardiology/American Heart Association Task Force on Clinical Practice Guidelines. Hypertension. 2018 Jun;71(6):e116-e35.

23. Williams B, Mancia G, Spiering W, Agabiti Rosei E, Azizi M, Burnier M, et al. 2018 ESC/ESH Guidelines for the management of arterial hypertension. Eur Heart J. 2018;39(33):3021-104.

24. World Medical Association. World Medical Associatioin Declaration of Helsinki: ethical principles for medical research involving human subjects. JAMA. 2013 Nov 27;310(20):2191-4

25. van Delden JJ, van der Graaf R. Revised CIOMS International Ethical Guidelines for Health-Related Research Involving Humans. JAMA. 2017 Jan;317(2):135-6.

26. Fernández MTC, Duharte JF, Maren DM, Botiel LBB, Diarra O. Hallazgos clínicos e histomorfológicos en pacientes con esteatosis hepática no alcohólica. MediSan. 2014;18(8):1173-9. Spanish

27. Fondén JD, Pereira Despaigne $\mathrm{OL}$, Columbié $\mathrm{AL}$, Del Valle Díaz S, Hodelín Tablada R Relación entre los hallazgos ecográficos, laparoscópicos e histológicos en pacientes con esteatosis hepática no alcohólica. MediSan. 2015;19(03):34553. Spanish

28. Canciano Chirino E, Iglesia Reyes CK, de Armas Romero I, Fandiño González L, Iglesia Reyes $\mathrm{ME}$, Río Ponciano O. Hígado graso no alcohólico como marcador de calidad de vida en mujeres de edad mediana. Rev Cubana Obstetr Ginecol. 2011;37(4):533-40. Spanish.

29. Creagh García J, Suárez Sori B, Hernández Rodríguez M, Martínez Paradela T. Resultados de la biopsia hepática en el diagnóstico del hígado graso no alcohólico. Rev Arch Médico Camagüey. 2017 Jul-Aug;21(4):518-27. Spanish.

30. del Busto Mesa A, Cabrera Rego JO, Guanche Valenciano O. Cintura hipertrigliceridémica y 
enfermedad por hígado graso no alcohólico en pacientes hipertensos. Rev Cubana Med. 2017 Jan-Mar;56(1):4-14. Spanish.

31. Fleischman MW, Budoff M, Zeb I, Li D, Foster T. NAFLD prevalence differs among hispanic subgroups: the Multi-Ethnic Study of Atherosclerosis. World J Gastroenterol. 2014 May 7:20(17):4987-93.

32. Matteoni L, Boente L, Soares D, Leal R, Campos F, César Araújo, et al. [Nonalcoholic fatty hepatic disease: relevance of the diagnosis on abdominal ultrasound]. Gaz Méd Bahia. 2011 Jan-Jun;81(1):7-9. Portuguese.

33. Karnikowski $M$, Córdova $C$, d'Oliveira $R J$, d'Oliveira Karnikowski MG, de Toledo Nóbrega O. Non-alcoholic fatty liver disease and metabolic syndrome in Brazilian middle-aged and older adults. Sao Paulo Med J. 2007 Nov 1;125(6):333-7.

34. Parise ER, Salgado ALFDA, Secaf R, Cerri LMO, Cerri G. Prevalence of liver steatosis in abdominal ultrasound. GED. 2003 Nov;22(6):235-7.

35. Riquelme A, Arrese M, Soza A, Morales A, Baudrand R, Pérez-Ayuso RM, et al. Non-alcoholic fatty liver disease and its association with obesity, insulin resistance and increased serum levels of C-reactive protein in Hispanics. Liver Int. 2009 Jan;29(1):82-8.

36. Pérez M, Gonzáles L, Olarte R, Rodríguez NI, Tabares M, Salazar JP, et al. Nonalcoholic fatty liver disease is associated with insulin resistance in a young Hispanic population. Prev Med. 2011 Feb;52(2):174-7.

37. Bonet Gorbea M, Varona P, Chang de la Rosa M, García Roche R, Suárez Medina R, Arcia $\mathrm{N}$, et al. III Encuesta Nacional de Factores de Riesgo y Actividades Preventivas de Enfermedades No Transmisibles. Cuba 2010-2011 [Internet]. Havana: ECIMED; 2014 Aug 23 [cited 2015 Jun17]. Available at: https://www.researchgate .net/publication/325370475_III_Encuesta Nacional de factores de riesgo y activi dades preventivas de enfermedades no _trasmisibles_Cuba_2010-2011. Spanish.

38. Jiménez Acosta S, Díaz Sánchez ME, García Roche RG, Bonet Gorbea M, Wong Ordóñez I. Cambios en el estado nutricional de la población cubana adulta de diferentes regiones de Cuba. Rev Cubana Hig Epidemiol [Internet]. 2012 JanApr [cited 2020 May 22];50:4-13. Available at: http://scielo.sld.cu/scielo.php?script=sci arttext \&pid=S1561-30032012000100002. Spanish.

39. Akhavan Rezayat A, Dadgar Moghadam M, Ghasemi Nour M, Shirazinia M, Ghodsi H, Rouhbakhsh Zahmatkesh MR, et al. Association between smoking and nonalcoholic fatty liver disease: a systematic review and meta-analysis. SAGE Open Med. 2018 Jan 24;6:2050312117745223. DOI: $10.1177 / 2050312117745223$.

40. Guthold R, Stevens GA, Riley LM, Bull FC. Worldwide trends in insufficient physical activity from 2001 to 2016: a pooled analysis of 358 population-based surveys with 1.9 million participants. Lancet Global Health. 2018 Oct;6(10):e1077-e86.

41. Fattahi MR, Niknam R, Safarpour A, Sepehrimanesh M, Lotfi M. The prevalence of metabolic syndrome in non-alcoholic fatty liver disease: a population-based study. Middle East J Digest Dis [Internet]. 2016 Apr [cited 2020 Mar 14];8(2):131-7. Available at: https://www.ncbi .nlm.nih.gov/pmc/articles/pmid/27252820/

42. Povsic M, Wong OY, Perry R, Bottomley J. A structured literature review of the epidemiology and disease burden of non-alcoholic steatohepatitis (NASH). Adv Ther [Internet]. 2019 Jul [cited 2020 Aug 18];36(7):1574-94. Available at: https://www.ncbi.nlm.nih.gov/pmc/articles/ pmid/31065991/
43. Lonardo A, Nascimbeni F, Ballestri S, Fairweather D, Win S, Than TA, et al. Sex differences in nonalcoholic fatty liver disease: state of the art and identification of research gaps. Hepatology. 2019 Oct;70(4):1457-69.

44. Du T, Sun X, Yuan G, Zhou X, Lu H, Lin X, et al. Sex differences in the impact of nonalcoholic fatty liver disease on cardiovascular risk factors. Nutr Metab Cardiovasc Dis. 2017 Jan;27(1):63-9.

45. Ye ZL, Guo WQ, Li L. Sex-based differences in the association between nonalcoholic fatty liver disease and mortality. Clin Gastroenterol Hepatol. 2019 Jan;17(1):211-2.

46. McCracken E, Monaghan M, Sreenivasan S. Pathophysiology of the metabolic syndrome. Clin Dermatol [Internet]. 2018 Jan-Feb [cited 2020 Apr 18];36(1):14-20. Available at: https:// linkinghub.elsevier.com/retrieve/pii/S0738 -081X(17)30158-X

47. Younossi ZM, Stepanova M, Negro F, Hallaji S, Younossi Y, Lam B, et al. Nonalcoholic fatty liver disease in lean individuals in the United States. Medicine (Baltimore) [Internet]. 2012 Nov [cited 2020 Apr 18];91(6):31927. Available at: https://doi.org/10.1097/ MD.0b013e3182779d49

48. Sookoian S, Pirola CJ. Genetic predisposition in nonalcoholic fatty liver disease. Clin Molecular Hepatol. 2017 Mar;23(1):1-12.

49. Eslam M, Valenti L, Romeo S. Genetics and epigenetics of NAFLD and NASH: Clinical impact. J Hepatol. 2018 Feb;68(2):268-79.

50. Shen J, Wong GLH, Chan HL, Chan HLY, Yeung DKW, Chan RSM, et al. PNPLA3 gene polymorphism accounts for fatty liver in community subjects without metabolic syndrome. Aliment Pharmacol Ther [Internet]. 2014 Mar [cited 2020 Apr 18];39(5):532-9. Available at: https://doi .org/10.1111/apt.12609

51. Cintado A, Companioni O, Nazabal M, Camacho $\mathrm{H}$, Ferrer A, Fernández De Cossio ME, et al. Admixture estimates for the population of Havana City. Ann Human Biol [Internet]. 2009 May-Jun [cited 2020 Apr 20];36(3):350-60. Available at: http://www.tandfonline.com/doi/ full/10.1080/03014460902817984

52. Marcheco-Teruel B, Parra EJ, Fuentes-Smith E, Salas A, Buttenschøn HN, Demontis D, et al. Cuba: exploring the history of admixture and the genetic basis of pigmentation using autosomal and uniparental markers. PLoS Genet. 2014 Jul 24;10(7):e1004488.

53. Caldwell SH, Crespo DM. The spectrum expanded: cryptogenic cirrhosis and the natural history of non-alcoholic fatty liver disease. J Hepatol [Internet]. 2004 Apr [cited 2020 Apr 20];40(4):578-84. Available at: https://linkinghub.elsevier.com/retrieve/pii/ S0168827804000716

54. Vilar-Gómez E, Calzadilla-Bertot L, Wong VWS, Castellanos M, Aller-de la Fuente R, Metwally $\mathrm{M}$, et al. Fibrosis severity as a determinant of cause-specific mortality in patients with advanced nonalcoholic fatty liver disease: a multi-national cohort study. Gastroenterology [Internet]. 2018 Aug [cited 2020 Apr 21];155(2):443-57. Available at: https:// linkinghub.elsevier.com/retrieve/pii/S0016 $-5085(18) 34484-6$

\section{THE AUTHORS}

Marlen Ivón Castellanos-Fernández MD PhD (Corresponding author: mcastell@infomed.sld .cu), gastroenterologist with a doctorate in medical sciences. Full professor and senior researcher, Gastroenterology Institute, Medi- cal University of Havana, Cuba. https://orcid .org/0000-0001-7386-2064

Eduardo Crespo-Ramírez MD MS, gastroenterologist with a master's degree in satisfactory longevity. Associate professor and adjunct researcher, Medical University of Pinar del Río and the Pinar del Río Provincial Teaching Hospital, Cuba. https://orcid.org/0000-0003-1446 $-1230$

Sergio del Valle-Díaz MD MS, physician specializing in internal medicine and gastroenterology, with master's degrees in emergency medicine and medical education. Adjunct professor and adjunct researcher, Medical University of Santiago de Cuba, and Saturnino Lora Torres Provincial Clinical-Surgical Teaching Hospital, Santiago de Cuba. https://orcid .org/0000-0001-7535-0273

Eduardo Barreto-Suárez MD MS, physician specializing in gastroenterology and family medicine, with a master's degree in infectious diseases. Manuel Ascunce Domenech Provincial Clinical-Surgical Teaching Hospital, Camagüey, Cuba. Assistant professor, Medical University of Camagüey, Cuba. https://orcid.org/0000-0002 $-6384-5356$

Javier Orlando Díaz-Elías MD, MS, physician specializing in gastroenterology and family medicine, with a master's degree in infectious diseases. Calixto García University Clinical-Surgical Hospital, Havana, Cuba. Assistant professor, Medical University of Havana, Cuba. https://orcid .org/0000-0002-2160-6947

Lorenzo Santaló-Rodríguez MD, physician specializing in family medicine, Medical University of Havana, Cuba and Calixto García University Clinical-Surgical Hospital, Havana, Cuba. https://orcid.org/0000-0002-7857-4851

Sahili Corrales-Alonso MD, gastroenterologist. Faustino Pérez Hernández University ClinicalSurgical Teaching Hospital, Matanzas, Cuba. Associate professor and adjunct researcher, Medical University of Havana, Cuba. https:// orcid.org/0000-0002-1127-3114

Ignacio Morales-Martínez MD, physician specializing in gastroenterology and family medicine. Celestino Hernández Robau Provincial Oncology University Hospital, Villa Clara, Cuba. Associate professor and adjunct researcher, Medical University of Villa Clara, Cuba. https:// orcid.org/0000-0002-2016-2088

Elisa Cedeño-Ramírez MD, physician specializing in gastroenterology and family medicine. Manuel Fajardo Clinical-Surgical Teaching Hospital, Havana, Cuba. Instructor, Medical University of Havana, Cuba. https:// orcid.org/0000-0003-2541-3939

Teresita Pérez-González MD, physician specializing in gastroenterology and family medicine. Medical University of Havana, Cuba, 
and Iván Portuondo General Teaching Hospital, Artemisa, Cuba. https://orcid.org/0000-0003 $-0318-2914$

Sila María González-Suero MD MS, internist with a master's degree in emergency medicine. Associate professor, Gastroenterology Institute, Medical University of Havana, Cuba. https://orcid .org/0000-0003-4805-7391

Caridad Ruenes Domech MD MS, gastroenterologist with a master's degree in medical education. Associate professor and associate researcher, Gastroenterology Institute, Medical University of Havana, Cuba. https://orcid .org/0000-0001-9015-5257

Mirtha Infante-Velázquez MD PhD, gastroenterologist with a doctorate in medical sciences. Full professor and senior researcher, Gastroenterology Institute, Medical University of Havana, Cuba. https://orcid.org/0000-0003 $-1150-5197$

Susana Ángela Borges-González MD MS, psychiatrist with a master's degree in dementia care and research. Assistant professor, Gastroenterology Institute, Havana, Cuba. https://orcid.org/0000 $-0002-5510-3328$

Angela Elvírez-Gutiérrez MD MS, radiologist with a master's degree in diagnostic procedures. Associate professor, Gastroenterology Institute, Medical University of Havana, Cuba. https:// orcid.org/0000-0002-9740-1403

Sacha Lazo-del Vallín MD MS, radiologist with a master's degree in diagnostic media. Associate professor and associate researcher, Gastroenterology Institute, Medical University of Havana, Cuba. https://orcid.org/0000-0002 $-4001-9596$
Oscar Manuel Villa-Jiménez MD MS, gastroenterologist with a master's degree in infectious diseases. Assistant professor and adjunct researcher, Gastroenterology Institute, Medical University of Havana, Cuba. https://orcid .org/0000-0002-6675-584X

Liana Margarita Labrada-Moreno MD MS, biostatistician with a master's degree in infectious diseases. Instructor, Gastroenterology Institute, Medical University of Havana, Cuba. https://orcid .org/0000-0003-3867-2315

Submitted: January 27, 2020

Approved for publication: November 27, 2020 Disclosures: None 